\title{
INHERITANCE OF ADULT PLANT STRIPE RUST RESISTANCE IN WHEAT CULTIVARS GIZA160 AND GIZA168 \\ Shahin, A. A. ${ }^{1}$ and Kh.E.Ragab. ${ }^{2}$ \\ ${ }^{1}$ Wheat Disease Research Department, Plant Pathology Research Institute, Agriculture Research Centre, Egypt. \\ E-mail: a.a.shahin@hotmail.com.
}

${ }^{2}$ Wheat Research Department, Field Crops Research Institute, Agriculture Research Centre, Egypt.

\begin{abstract}
This investigation was carried out at the experimental farm of Sakha Agricultural Research Station, during wheat growing seasons from 2009 to 2011 . The objectives were to study the inheritance of adult plant resistance to stripe rust Puccinia striiformis f. sp. tritici [Pst] in the two Egyptian bread wheat cultivars Giza160 and Giza168 and identification of the most effective $Y r$ genes under study. Two Egyptian wheat cultivars (Triticum aestivum L.) i.e., Giza168 (resistant) and Giza160 (susceptible) to strip rust were crossed to four monogenic lines (Yr's) i.e., Kalyansona, Lee, Compair, and Jupateco R, which having strip rust resistance Yr's gene(s); Yr2, Yr7, Yr8 and Yr18+, respectively. Yellow rust reaction of the two cultivars and monogenic lines and their $F_{1}$ and $F_{2}$ populations were scored under field conditions. Artificial inoculation was done using mixture of physiological races of [Pst] at adult stage. Dominance of yellow rust resistance over susceptibility was noticed in most cases (in four out of five resistant by susceptible crosses). Segregation in the $F_{2}$ 's population showed the presence of two to three gene pairs controlling plant reaction against the $[P s t]$. The $Y r 8$ gene had high effectiveness of conferring resistance against $[P s t]$ under this investigation. Meanwhile, broad sense heritability estimates was high, thus early generation selection for stripe rust resistance could be effective for wheat improving for this character.
\end{abstract}

Keywords: Triticum aestivum; Yellow rust, Adult plant resistance.

\section{INTRODUCTION}

Wheat (Triticum aestivum L.) is the first important and strategic cereal crop for the majority of world's populations and Egypt as well. Stripe rust caused by Puccinia striiformis Westend $\mathrm{f}$. $\mathrm{sp}$. tritici $[P s t]$ is the major foliar disease of wheat, resulting in yield loss all over the world (Kolmer 1996). In Egypt, stripe rust attacked most of the commercial wheat cultivars, causing sever infection in North Delta Area (El-Daoudi et al., 1996). Yield loss of wheat can be in the years when stripe rust occurs, the calculated yield loss due to stripe rust varied among genotypes and locations with an overall range from 12.7-87\% (Bolat and Altay 2007). Moreover, the wheat cultivars become susceptible to rusts due to their narrow genetic base for resistance and the rapid rate of evaluation of the pathogen, making it necessary to search for new source(s) for resistance. Thus, the wheat production has been largely depended on the development and the use of resistant cultivars having diverse and well characterized genes. So far, nearly 40 stripe rust resistance genes have been identified and designated as Yr1 through Yr40 (Mclntosh et al., 2005; Kuraparthy et al., 2007). 
Many researches studied the inheritance of adult plant reaction to yellow rust and indicated the presence of two or three genes controlling resistance. (Satinder et al., 2008) studied the $F_{2}$ segregations of some Indian wheat cultivars and found that resistance was recessive over susceptibility and was controlled by two genes. A significant step toward a better control the strip rust adult plant resistance is identification and conferring of genes controlled of this disease (Hussain et al., 1999). Recently, (Hussain et al., 2011) reported that, additive, dominance and epistasis were involved in the expression of genes for yellow rust resistance in wheat. Also they found that lower estimates of narrow sense heritability. Moreover, (Kaur and Bariana 2010) found three genetically independent genes for adult plant resistance to stripe rust in some Australian wheat cultivars. Therefore, the main purpose of this work was to study inheritance of wheat resistance to stripe rust caused by a collection of different races of [Pst] and determine the genetic factors (genes) governing the inheritance of resistance to strip rust in wheat cultivars at adult stage under field conditions.

\section{MATERIALS AND METHODS}

This investigation was carried out at the experimental farm of Sakha Agricultural Research Station, Egypt, during the successive wheat growing seasons from 2009 to 2011.

\section{Plant materials}

Six bread wheat parents exhibited different level of resistance or susceptibility to yellow rust were used in this investigation; two Egyptian cultivars namely Giza168 and Giza160 and four $Y r$ monogenic lines having stripe rust resistance genes $\mathrm{Yr}$, $\mathrm{Yr}$ 7, Yr8 and $\mathrm{Yr}_{18}{ }^{+}$. The four $\mathrm{Yr}$ monogenic lines were provided by Dr. Colin R. Wellings, Sydney University and the two Egyptian bread wheat cultivars were provided by Wheat Ddepartment, Field Crops Institute, Agricultural Research Center (ARC), Egypt. Name, pedigree, Yr's gene and seed origin as well as their adult plant field response to stripe rust in the field during 2009/2010 are presented in Table 1.

Table 1. Name, pedigree, Yr's genes and seed origin as well as adult plant field response to stripe rust for two Egyptian bread wheat cultivars and four monogenic lines during 2009/2010 season.

\begin{tabular}{|c|c|c|c|c|}
\hline Genotype & Pedigree & (Yr's) gene & $\begin{array}{l}\text { Adult plant } \\
\text { response }{ }^{\alpha}\end{array}$ & Seed origin \\
\hline Kalyansona & PENJAMO T 62 / GABO 55 & Yr2 & $\mathrm{S}$ & Australia \\
\hline Lee & HOPE / TIMSTEIN & Yr7 & $\mathrm{S}$ & Australia \\
\hline Compair & $\begin{array}{c}\text { CHINESE SPRING / AEGLOPSE } \\
\text { COMOSUM }\end{array}$ & Yr8, APR & $\mathrm{R}$ & Australia \\
\hline Jupateco R & $\begin{array}{c}\text { II } 12300 \text { // LR64A / } 8156 \text { /3/ } \\
\text { NORTENO M } 67\end{array}$ & $\mathrm{Yr}^{+} 8^{+}$ & MS-S & Australia \\
\hline Giza 168 & $\begin{array}{c}\text { MRL / BUC // SERI } \\
\text { CM93046-8M-0Y-0M-2Y-0B-0SH }\end{array}$ & unknown & MR & Egypt \\
\hline Giza 160 & CHENAB / GIZA155 & unknown & $\mathrm{s}$ & Egypt \\
\hline
\end{tabular}

${ }^{a}$ Adult plant disease resistance estimation is based on modified Cobb Scale and has two components: disease severity and infection type. $T=$ Trace severity; $5=5 \%$ severity......etc.; I=immune, R=resistance; MR=moderately resistance; MS=moderately susceptible; and $S=$ susceptible. 
In 2008/2009 season, the six studied parental genotypes were sown in three planting dates to synchronize the flowering differences. Each parent was represented by two rows; $2.5 \mathrm{~m}$ long in each planting date. Nine crosses were designed to produce the $F_{1}$ 's hybrid seeds. The resulted $F_{1}$ 's are as follow: Giza168/Compair, Giza168/Lee, Giza168/Jupateco R, Giza168/Kalyansona, Giza160/Compair, Giza160/Lee, Giza160/Jupateco R, Giza 160/Kalyansona and Giza168/Giza 160.

In 2009/2010 season, the $F_{1}$ seeds were sown in rows of $3 \mathrm{~m}$ long and $30 \mathrm{~cm}$ apart and spaced widely at $30 \mathrm{~cm}$ apart in order to allow for the production of the largest amount of $F_{2}$ seed.

In 2010/2011 season, the evaluation experiment was sown. The nine $F_{1}$ 's, nine $F_{2}$ 's and their six parents were arranged in randomized complete block design with three replications. The two parents, $F_{1}$ and $F_{2}$ of each cross were planted in rows $4.2 \mathrm{~m}$ long, $30 \mathrm{~cm}$ apart and $20 \mathrm{~cm}$ between plants. Each plot consisted of 9 rows (one for each for $P_{1}, P_{2}$ and $F_{1}$ and 6 for $F_{2}$ ). The experiment was surrounded by mixture of highly susceptible wheat cultivars (Morocco, and Giza160) to serve as a spreader to disseminate the stripe rust urediniospores of pathogen $[P s t]$.

\section{Inoculation and disease assessment}

The inoculation of all plants was carried out at wheat booting stage according to the method of (Tervet and Cassel 1951). The yellow rust reaction was recorded at the adult stage of the tested plants when rust severity reached $30 \%$ in the susceptible cultivars of the spreader. Stripe rust severity (\%) was recorded for all entries from the time of rust first appearance then every seven days until the early dough stage of wheat. Plant reaction (infection type) expressed in five types according to (Stakman et al., (1962). In this method, immune, resistance, moderately resistance, moderately susceptible and susceptible infection types (IT) were symbolized as I, R, MR, MS and S, respectively. Plants having $R$, and $M R$ infection types were pooled together and considered as resistance, while plants with MS and $S$ infection types were considered as susceptible ones. For quantitative analysis, field response was converted into an average coefficient of infection ( $\mathrm{ACl}$ ) following the method proposed by (Saari and Wilcoxson 1974). ACl obtained by multiplying infection severity by an assigned constant values namely, 0.0 , $0.2,0.4,0.8$ and 1 for I, R, MR, MS, and S infection types, respectively.

\section{Statistical and genetic analysis}

Chi squire test $\left(X^{2}\right)$ was used to test significance of difference between observed and expected ratios in $F_{2}$ populations for yellow rust reaction according to (Steel and Torrie, 1960). The frequency distributions of the $F_{2}$ populations of the studied crosses were done by dividing the field response into 11 classes i.e. I, R, 10R, 10MR, 20MR, 10MS, 10S, 30S, 40S, $50 S$ and $60 \mathrm{~S}$. Some genetic parameters were estimates i.e., means of parents, $F_{1}$ and $F_{2}$, environmental variance $V E=\left[\left(V P 1+V P_{2}+V F_{1}\right) / 3\right]$ Allard 1960 , phenotypic variance $V P=V F_{2}$, genotypic variance $V G=V P-V E$, broad sense heritability $\left(h^{2} \mathrm{~b} \%=(\mathrm{VG} / \mathrm{VP}) \times 100\right.$ (Falconer and Mackay 1996), the expected genetic advance at $5 \%$ selection intensity $\left(\Delta \mathrm{g} \%=(\mathrm{k} \times(\mathrm{VP}))^{0.5}\right.$ 
$\left.\times h^{2} b\right)$ (Allard 1960) and genotypic coefficient of variation GCV\% = [(VG/F ${ }^{2}$ mean $\left.) \times 100\right]$ (Singh and Naraynan 2000).

\section{RESULTS}

Field test was carried out to study the inheritance of wheat resistance to stripe rust at adult plant stage under field conditions during 2010/2011 growing season at Sakha Agricultural Research Station.

The field test was applied to the $P_{1}, P_{2}, F_{1}$ and $F_{2}$ populations for each of the nine studied crosses. Giza168 consistently expressed high resistance to stripe rust, with TMR disease field response, while Giza 160 was highly susceptible to stripe rust with 605 disease field response. On the other hand, the four monogenic parents, i.e. Kalyansona, Lee, Compair, and Jupateco $R$, showed $S, S, R$, and MS-S, disease field response, respectively, Table 2. The adult plants of the crosses of Giza168 cultivar with the four monogenic lines showed resistance to yellow rust except for Giza168/Lee, Table 2. The $F_{2}$ adult plants came from the crosses between Giza168 and each of Compair, Lee, Jupateco R and Kalyansona segregated into 175R:26S, 24R:186S, 183R:18S and 180R:26S plants, with expected ratios 57:7, 7:57, 15:1 and 57:7, respectively, Table 3.

Table 2. The adult plant reaction to yellow rust under field condition for nine bread wheat crosses and their parents.

\begin{tabular}{|l|c|c|c|}
\hline \multirow{2}{*}{ Cross } & \multicolumn{3}{|c|}{ Adult plant reaction to yellow rust } \\
\cline { 2 - 4 } & $\mathbf{P}_{\mathbf{1}}$ & $\mathbf{P}_{\mathbf{2}}$ & $\mathbf{F}_{\mathbf{1}}$ \\
\hline Giza 168/Compair & TMR & $5 \mathrm{R}$ & $10 \mathrm{MR}$ \\
\hline Giza 168/Lee & TMR & $30 \mathrm{~S}$ & $10 \mathrm{~S}$ \\
\hline Giza 168/Jupateco R & TMR & $5 \mathrm{MS}-\mathrm{S}$ & $10 \mathrm{R}$ \\
\hline Giza 168/Kalyansona & TMR & $10 \mathrm{~S}$ & $20 \mathrm{MR}$ \\
\hline Giza 160/Compair & $60 \mathrm{~S}$ & $5 \mathrm{R}$ & $10 \mathrm{R}$ \\
\hline Giza 160/Lee & $60 \mathrm{~S}$ & $30 \mathrm{~S}$ & $20 \mathrm{~S}$ \\
\hline Giza 160/Jupateco R & $60 \mathrm{~S}$ & $5 \mathrm{MS}-\mathrm{S}$ & $20 \mathrm{~S}$ \\
\hline Giza 160/Kalyansona & $60 \mathrm{~S}$ & $10 \mathrm{~S}$ & $30 \mathrm{~S}$ \\
\hline Giza 168/Giza 160 & TMR & $60 \mathrm{~S}$ & $20 \mathrm{MR}-\mathrm{MS}$ \\
\hline
\end{tabular}

$\mathrm{R}=$ resistance, $\mathrm{MR}=$ moderately resistance, $\mathrm{MS}=$ moderately susceptible and $\mathrm{S}=$ susceptible and $\mathrm{T}=\mathrm{Trace}$.

Giza160 crosses with the four $Y r$ monogenic lines showed adult plants susceptibility to yellow rust except for the cross Giza160/Compair, Table 2. The $F_{2}$ generation segregated into 30R:180S, 0R:205S, 10R:195S and 20R:189S plants with expected ratios 13:3, 0:1, 1:15 and 7:57, respectively, Table 3. The $F_{1}$ plants of the cross Giza168/Giza160 was resistant to yellow rust, while the $F_{2}$ population segregated into 40R:120S with expected ratio 3:13, Table 3. 
Table 3. Adult plant response for stripe rust; observed hypothetical ratios and chi-square and probability values for nine wheat $F_{2}$ populations inoculated with $P$ st under field conditions during 2010/2011.

\begin{tabular}{|c|c|c|c|c|c|c|}
\hline \multirow[b]{2}{*}{ Cross } & \multicolumn{3}{|c|}{ No. of plants } & \multirow{2}{*}{$\begin{array}{c}\text { Hypothetical } \\
\text { ratio }\end{array}$} & \multirow{2}{*}{$\begin{array}{c}\text { Chi- } \\
\text { Squared } \\
\left(\chi^{2}\right)\end{array}$} & \multirow{2}{*}{$P$. value ${ }^{\Omega}$} \\
\hline & Resistant & Susceptible & Total & & & \\
\hline Giza168/Compair & 175 & 26 & 201 & $57: 7$ & 0.823 & $0.50-0.25$ \\
\hline Giza 168/Lee & 24 & 186 & 210 & $7: 57$ & 0.052 & $0.90-0.75$ \\
\hline Giza168/Jupateco R & 183 & 18 & 201 & $15: 1$ & 2.46 & $0.25-0.10$ \\
\hline Giza 168/Kalyansona & 180 & 26 & 206 & $57: 7$ & 0.599 & $0.50-0.25$ \\
\hline Giza 160/Compair & 30 & 180 & 210 & $3: 13$ & 2.747 & $0.10-0.05$ \\
\hline Giza 160/Lee & 0 & 205 & 205 & $0: 1$ & - & $>0.99$ \\
\hline Giza 160/Jupateco R & 10 & 195 & 205 & $1: 15$ & 0.658 & $0.50-0.25$ \\
\hline Giza 160/Kalyansona & 20 & 189 & 209 & $7: 57$ & 0.402 & $0.75-0.50$ \\
\hline Giza 168/Giza 160 & 40 & 170 & 210 & $3: 13$ & 0.012 & $0.90-0.75$ \\
\hline
\end{tabular}

${ }^{\Omega} P$ values higher than 0.05 indicate no significant of $\chi 2$.

Parents, $F_{1}$ 's and $F_{2}$ 's Population mean and variance based on $\mathrm{ACl}$ values were used to estimate some genetic parameters Table $4 . \mathrm{ACl}$ mean values of parent ranged from 1.8 for Giza168 to 31.0 for Giza 160; from 2.1 for $F_{1}$ of the cross Giza168/Jupateco $R$ to 30.5 for $F_{1}$ of the cross Giza160/Kalyansona; from 4.3 for the $F_{2}$ population of the cross Giza168/Jupateco $R$ to 35.1 for $F_{2}$ population of the cross Giza160/Lee, Table 4.

Table 4: Genetic parameters based on average coefficient of infection for yellow rust of eight wheat crosses.

\begin{tabular}{|c|c|c|c|c|c|c|c|c|c|c|}
\hline \multirow{3}{*}{ Cross } & \multicolumn{10}{|c|}{ Genetic parameter } \\
\hline & \multicolumn{4}{|c|}{ Mean } & \multicolumn{3}{|c|}{ Variance } & \multirow{2}{*}{$h^{2} b \%$} & \multirow{2}{*}{$\Delta \mathbf{g} \%$} & \multirow{2}{*}{ GCV\% } \\
\hline & $\mathbf{P}_{1}$ & $\mathbf{P}_{2}$ & $F_{1}$ & $\mathbf{F}_{2}$ & V P & VE & VG & & & \\
\hline Giza 168/Compair & 1.8 & 4.6 & 4.4 & 5.4 & 16.7 & 1.3 & 15.4 & 92 & 25.3 & 23.0 \\
\hline Giza 168/Lee & 1.8 & 21.0 & 11.5 & 16.0 & 80.0 & 7.7 & 72.3 & 90 & 118.9 & 8.3 \\
\hline Giza 168/ Jupateco R & 1.8 & 8.2 & 2.1 & 4.3 & 7.9 & 0.3 & 7.6 & 96 & 12.5 & 26.1 \\
\hline Giza 168/Kalyansona & 1.8 & 11.5 & 7.6 & 5.0 & 14.1 & 5.1 & 9.0 & 64 & 15.1 & 20.6 \\
\hline Giza 160/Compair & 31.0 & 4.6 & 7.6 & 19.5 & 186.1 & 4.4 & 181.7 & 98 & 297.7 & 7.1 \\
\hline Giza 160/Lee & 31.0 & 21.0 & 21.5 & 35.1 & 235.9 & 10.8 & 225.1 & 95 & 369.2 & 4.0 \\
\hline Giza 160/Jupateco R & 31.0 & 8.2 & 17.5 & 21.9 & 93.8 & 9.9 & 83.9 & 90 & 138.1 & 5.9 \\
\hline Giza 160/Kalyansona & 31.0 & & 30.5 & 23.7 & 268.9 & 9.3 & 259.6 & 97 & 425.5 & 5.6 \\
\hline
\end{tabular}

PV, EV and GV = Phenotypic, environment and genetic variance, respectively. $h^{2} b=$ Broad sense heritability. $\Delta \mathbf{g} \%=$ the expected genetic advance under selection. GCV $\%=$ genotypic coefficient of variation.

Regarding variance estimates, environmental (VE), phenotypic (VP) and genotypic (VG) variances ranged from $0.3,7.9$ and 7.6 for the cross Giza 168/Jupateco R to 10.8, 235.9 and 225.1 for the cross Giza 160 / Lee, respectively, Table 4 . Broad sense heritability $\left(h^{2} b \%\right)$ estimates ranged from 97.7 for the cross Giza 160/Compair to 64.0 for cross Giza 168/Kalyansona, Table 4 . The genetic advance from selection $(\Delta \mathbf{g} \%)$ ranged from 425.5 for cross Giza160/Kalyansona to 12.5 for cross Giza168/Jupateco R. Meanwhile 
genetic coefficient of variation ranged from 4.0 for cross Giza 160/Lee to 23.0 for cross Giza 168/Compair, Table 4. Frequency distribution of yellow rust reaction as infection type and severity in the $F_{2}$ populations of the studied crosses and their parents and $F_{1}$ are illustrated in Fig.1. Regarding resistant by susceptible crosses, the $F_{1}$ plants field response were close to the resistant parent (the crosses Giza 168/Jupateco R and Giza160/Compair); close to the susceptible parent in cross Giza168/Lee; closed to mid parent in the cross Giza168/Kalyansona.

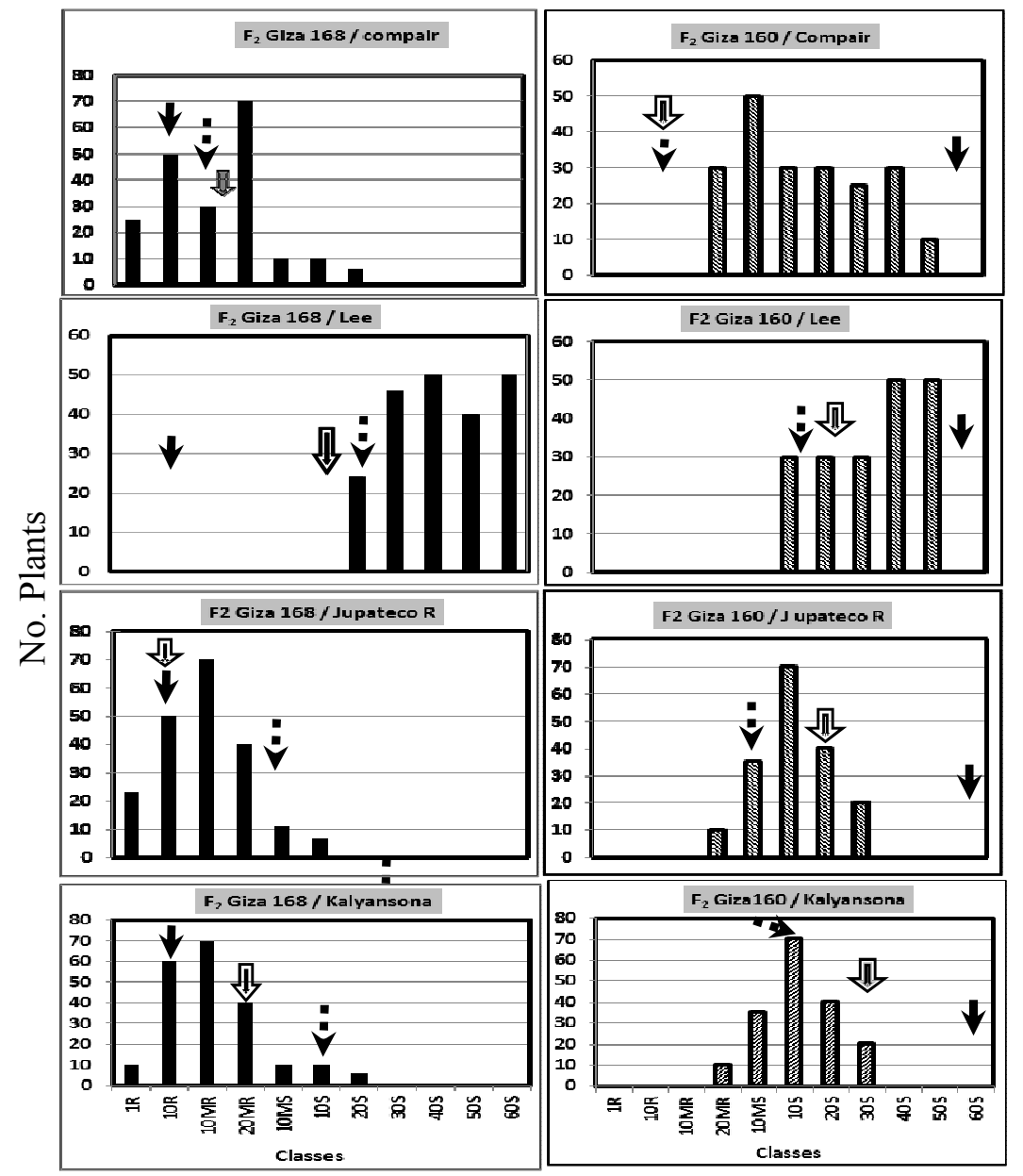

Fig. 1: Frequency distribution of yellow rust reaction as infection type and severity in the $F_{2}$ populations of eight bread wheat crosses $P_{1}\left({ }^{\downarrow}\right)$, $P_{2}\left({ }^{\downarrow}\right)$ and $F_{1}(j)$ indicate the class of the two parents and $F 1$ of each cross. 
With respect to $F_{2}$ frequency distribution of the crosses between Giza160 (susceptible) and the four $Y r$ monogenic lines, high level of resistant to yellow rust were found with the line Compair which carry $Y r 8^{+} A P R$ resistant gene.

\section{DISCUSSION}

Wheat yellow rust adult plant resistance genes are the most important in terms of widespread distribution and durability. Therefore, the focus has been on the resistance genes expressed at the adult stage which theoretically reducing the selection pressure for pathogen virulence.

The $F_{1}$ plants field response showed dominance of resistance over susceptibility in the two crosses Giza168/Jupateco R, and Giza160/Compair; dominance of susceptibility over resistance in the cross Giza168/Lee. Partial dominance recorded in the cross Giza168/Kalyansona, Table 2 and Fig. 1. (Farahania et al., 2014) reported complete dominance for resistant to yellow rust resistance. The $F_{2}$ populations field response of the crosses between the susceptible parent Giza160 with the four studied $Y r$ monogenic lines showed high level of resistance in cross Giza160/Compair indicating the effectiveness of $Y r 8+A P R$ gene conferring resistance against [Pst] under this investigation. The obtained results of $F_{2}$ segregation ratios of Giza168 crosses indicated that, three dominant and/or recessive gene pairs controlling resistance in the crosses Giza168/Compair, Giza168/Kalyansona and Giza168/Lee with segregation ratios of $57: 7,57: 7$ and $7: 57$, respectively. Meanwhile, two dominant gene pairs found to be controlling resistance in the cross Giza168/Jupateco R with ratio 15:1. This also suggesting that Giza168 parent contribute two genes while the other gene contributed by the monogenic lines.

Concerning the crosses performed between Giza160 with the same four Yr's, the results indicated that two recessive gene pairs found to be conferring resistance in the crosses Giza160/Compair and Giza160/Jupateco $R$ with segregation ratios $3: 13$ and $1: 15$, respectively. Three recessive gene pairs found to be controlling resistance in the cross Giza 160/Kalyansona with segregation ratio 7:57. It could be concluded from these results that, incorporation of the four mentioned Yr's monogenic lines except for Lee, in cultivar such as Giza 168 would induce genetic advance toward yellow rust resistance. (Chen 2007) results indicated that resistance to stripe rust is controlled by complementary genes, (Anpilogova 1983) pointed out resistance to stripe rust is controlled by partial dominance or recessive with certain crosses. Moreover, (Xianming and Roland, 1992) indicated that some cultivars may include two genes for resistance to stripe rust, one was dominant and the other was recessive gene. Also, our results agreed with (Singh et al., 2005), (Randhawa et al., 2012) and (Shahin 2014) who suggested that accumulating 4 or 5 durable resistance genes to the susceptible cultivars these genes have small to intermediate effect but additive to gain many cultivars in addition to Lr34 and Yr18 that are contributing towards their durable resistance. (Zaifeng et al., 2013) phenotype 
the cross PBW343 $\times$ Kenya Kudu $F_{2}$ population for yellow rust reaction in the field, they reported that, minimum of four minor genes having additive effects segregated in the population and were likely derived from both parents.

The estimation of heritability helps in predicting the behavior of the succeeding generations and the appropriate selection procedure adapted. The main portion of total variance in all studied crosses was mainly due to the genetic variance (Table 4); this reflected the high estimates of broad sense heritability and the expected genetic advance under selection in most crosses. These findings are in agreement with those reported by (Ali et al., 1994), (Yadav et al., 1998), (Ageez and Boulot 1999), (Zhang et al., 2001), (Hammad 2003) and (Ragab 2005).

\section{CONCLUSSION}

This study demonstrated the presence of two or three genetically independent genes for adult plant resistance to stripe rust in the Egyptian wheat cultivar G.168. Resistance carried by the two cultivars is based on different gene combinations. This cultivar being to be used as donor sources for improvement of stripe rust resistance in wheat breeding programs. The $Y r 8+A P R$ gene had high effectiveness of conferring resistance against [Pst] under this investigation.

\section{REFERENCES}

Ageez, A.A. and O.A. Boulot (1999). Quantitative determination of the gene action of leaf rust resistance in a 7-parent diallel cross of wheat. Egypt. J. Appl. Sci., 14 (6): 216-226.

Ali, I.; A.P. Roelfs and J. Huerta-Espino (1994). Inheritance of leaf rust resistance in wheat cultivars Moroco and Little Clup. Plant Disease, 78: 383-384.

Allard, R.W. (1960). Principles of plant breeding. John wiley and sons, New York.

Anpilogova, L.K. (1983). Inheritance of resistance to yellow rust in wheat hybrids at different phases of plant growth. Genetika USSR., 19:16741679 (C.F. Rev. PI Pathol. 1984).

Bolat, N, and Altay F (2007). Comparison of different methods used in calculating the effect of stripe rust on wheat grain yields. Acta Agronomica Hungarica, 55: 89-98.

Chen, X.M. (2007). Challenges and solutions for stripe rust control in the United States. Australian Journal of Agricultural Research, 58, 648655.

El-Daoudi, Y.H.; Ikhlas Shafik; Enayat H. Ghanem; S. Abu El-Naga; R. Mitkees; S. Sherif; M. Khalifa and A.A. Bassiouni (1996). Stripe rust occurrence in Egypt and assessment of grain yield losses in 1995. Proceedings de Symposium Regional surles Maladies des Cereales et des Legumineuses Alimentaires. 11-14, 1996, Ra, Morroc, pp.341-351. 
Falconer, D.S. and T.F.C. Mackay (1996). Introduction to quantitative genetics. $4^{\text {th }}$ Edn., Longmans Green, Harlow, Essex, UK

Farahania, H.; M. Khodarahmib; Kh. Mostafavia and S Ebrahimnejadc (2014). Inheritance of resistance to wheat yellow rust at adult plant stage. Phytopathology and Plant Protection, 47(10):1202-1208

Hammad, S.M. (2003). Traditional and molecular breeding of wheat in relation to rusts resistance Ph.D. Thesis, Tanta Uni., Egypt.

Hussain, M.; M. H. Chaudhry; A. Rehman; J. Anwar; S. B.Khan. and M. Hussain (1999). Development of durable rust resistance in wheat. Pakistan J. phytopathology 11: 130-139.

Hussain F.; M. Ashraf; A. H. Muhammad; N. Hussain and R. A. Sial (2011). Genetic studies in wheat for leaf rust resistance (Puccinia recondita). African Journal of Biotechnology, 10(16): 3051-3054.

Kaur, J. and H.S. Bariana (2010). Inheritance of adult plant stripe rust resistance in wheat cultivars kukri and sunco. Journal of Plant Pathology. 92: 391-394.

Kolmer, J. A. (1996). Genetics of resistance to leaf rust. Ann. Rev. hytopathol. 34, 435-455.

Kuraparthy V.; P. Chhuneja; H. S. Dhaliwal; S. Kaur; R. L. Bowden and B. S. Gill (2007). Characterization and mapping of cryptic alien introgression from Aegilops geniculata with novel leaf rust and stripe rust resistance genes Lr57 and Yr40 in wheat. Theor Appl. Genet. 114: 1379-1389.

Mclntosh R. A.; K. M. Devos Dubcovsky; W. J. Rogers; C.F. Morris; R. Appels and O. A. Anderson (2005). Catalogue of gene symbols for wheat: 2005 supplement http://www.wheat.pw.usda.gov.

Ragab, Kh.E.(2005). Utilization of modern genetic techniques in studing resistance of wheat to wheat rusts .M.Sc. Thesis. Minufiya University. Egypt.

Randhawa, H.; B. J. Puchalski; M. Frick; A. Goyal; T. Despins; R. J. Graf; A. Laroche; and D. A. Gaudet (2012). Stripe rust resistance among western Canadian spring wheat and triticale varieties. Can. J. Plant Sci. 92: 713-722.

Saari, E.E. and R.D. Wilcoxson (1974). Plant disease situation of highyielding durum wheat in Asia and Africa. Annual Review of Phytopathology, 12:49-68.

Satinder K., U. K. Bansal Khanna and R. G. Saini (2008). Genetics of leaf and stripe rust resistance in a bread wheat cultivar Tonichi. Journal of Genetics, 87: 2.

Shahin A.A. (2014). Resistance to stripe rust disease in some Egyptian wheat cultivars. J. Plant Prot. and Path., Mansoura Univ., Vol. 5(11):983-993.

Singh, P. and S.S. Naraynan (2000). Biometrical techniques in plant breeding. Kalani publishers, Ludhiana. New Delhi. Nodi (U.P).

Singh, R.P.; Huerta J. Espino; H.M. William (2005). Genetics and breeding for durable resistance to leaf and stripe rusts in wheat. Turkisk J. Agric. And Forestry. 29(2):121-127. 
Stakman, E.C.; D.M. Stewart and W.Q. Loegering (1962). Identification of physiologic races of puccinia graminis var. tritici. ARS, USDA., Agr. Res. Serv. Bull. E6/7.53pp.

Steel, R.G.D. and T.H. Torrie (1960). Principles and procedures of statistics. MC-Graw HILL, N.Y.; USA.

Tervet, I. and R.C. Cassel (1951). The use of cyclone separation in race identification of cereal rusts. Phytopathology, 41:282-285.

Xianming Chen and Roland Line (1992). Gene for resistance to stripe rust in wheat. Crop Sci. 32:692-696.

Yadav B.; C.S. Tyagi and D. Singh(1998). Genetical studies and transgressive segregation for field resistance to leaf rust of wheat. Wheat Information Service 87: 15-21.

Zaifeng Li; S. Singh; R. P. Singh; E. E. López-Vera and J. Huerta-Espino (2013). Genetics of resistance to yellow rust in PBW343 $\times$ Kenya Kudu recombinant inbred line population and mapping of a new resistance gene YrKK. Mol. Breeding, 32(4): 821-829

Zhang, Z. J.; G. H. Yang; G.H. Li; S.L. Jin and X.B. Yang (2001). Transgressive segregation, heritability and number of genes controlling durable resistance to stripe rust in one Chinese and two Italian wheat cultivars. Phytopathology 91: 680-686.

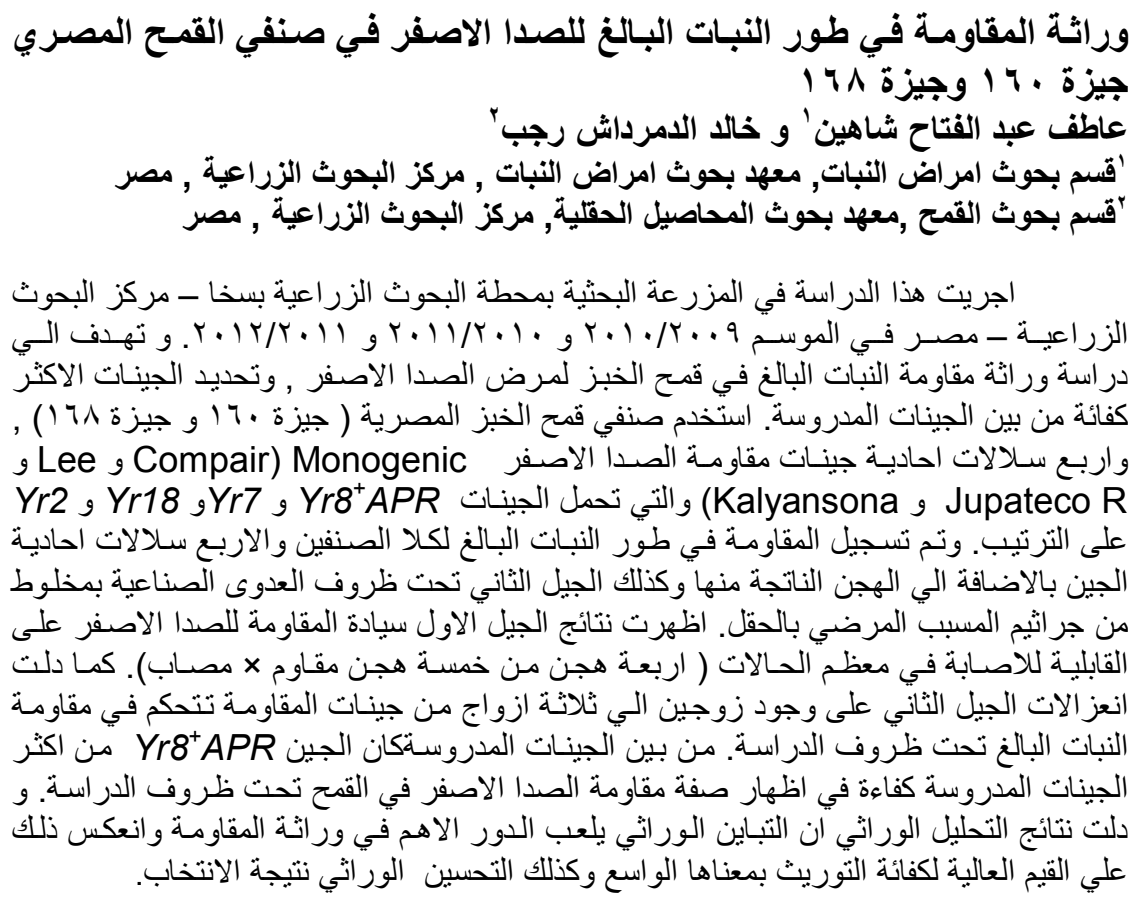

